\title{
APPENDIX TO THE CLASSIFICATION OF RURAL SETTLEMENTS IN THE REPUBLIC OF SERBIA ACCORDING TO THEIR URBAN-MORPHOLOGICAL CHARACTERISTICS
}

\author{
D. Dopudja \\ Peoples' Friendship University of Russia \\ Miklukho-Maklaya str., 6, Moscow, Russia, 117198
}

The given article has a goal to present a method of built structure spatial analysis from urbanmorphological aspect, through an analytical overview of Serbian village settlements, and to propose its' update, in accordance with changes that took place in last few decades.

Key words: village, settlement, rural, urban morphology, genesis, spatial development, reclassification

Analysis of a settlement according to its urban - morphological characteristics represents one of several classifications, simultaneously used in Serbian professional practice in order to determine characteristics of a rural settlement. This approach stems from the turbulent history of Balkan Peninsula, due to which, the once single corpus of Serbian architecture, was maturing within three different spheres of influence: Slavic, Central European, and Oriental. Such a dichotomy, catalyzed with an absolute spatial ephemerality of the aforementioned influence spheres - in which literally every single settlement was developing within at least two, determined an introduction of time - space continuum inside urbanistic and spatial development practice [1;2].

As a concept, morphological studies are no stranger to Russian science; however, in most cases, they are related to linguistics, philosophy, geography, and similar sciences. In the architectural profession, the use of (urban) morphology as a scientific discipline has yet to take hold [3]. Therefore, in order to more closely explain approach and methods that were used in making of accompanying classification, we will first explain the very notion of morphological studies in urbanism, and only after that, we will represent an existing classification of rural settlements in Republic of Serbia and suggest some amendments in order to improve it.

The term "morphology" was created as a coin from Greek words "morphe" (form) and "logos" (science), and, therefore, can be defined as the science about the origin and development of the form [4]. The morphology, as a form of research, represents an integral part of many scientific disciplines, and is used as a method of explaining the phenomena and processes related to the creation of specific shapes. The essential characteristics of all morphological investigations are principle of joint exploration of form and structure, and determination of common morphological characteristics (comparative analysis).

According to architect Vladan Djokic, PhD, urban morphology is "a discipline that deals with the study of built structures and open spaces form origin and later development 


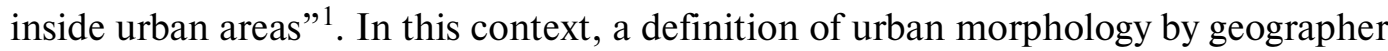
and urban planner Milan Vresk is also significant: "The urban morphology is a branch of urban geography that studies the morphological structure of the city within its threedimensional characteristics" . Analyzing Vresk's capital work, "Fundamentals of urban geography", Djokic concludes that "By the morphological structure of the city, author thinks of spatial arrangement and relationships of morphological elements in the metropolitan (urban) area, such as street, squares, plots, public places, blocks, buildings, etc. Their specific features, such as building density, their size, shape, position, appearance, etc, distinguish these elements. Morphological structure of the city largely depends of his spatial plan, development land usage, meaning and deployment of functional parts of the city, the city's development in the past and present" 3 .

In accordance with the methodology of the urban morphology, in the territory of the Republic of Serbia, it is possible to allocate two basic forms of rural settlements: a dispersed structure village settlement and one with compact structure [5; 6]. Criteria, according to which those settlements are being classified, are:

- The gross density of the settlement's built structure;

- The possibility or impossibility to determine settlement boundaries;

- The size and structure of estates, as well as distance between them.

Both village types, (compact and dispersed structure villages), are divided into subtypes, in accordance with a more detailed analysis of their characteristics. The division shown below is an existing division of rural settlements in the Republic of Serbia, with newly generated forms attached (in italic). Urban - morphological properties of the newly fixated forms will be presented after characteristics of the "old" settlement types, together with argumentation of their classification into one or another group.

\section{- Compact structure village settlement:}

Settlement with semi compact structure:

- Systematically developed (planned) settlement;

- Subsequently planned settlement;

- Spontaneously formed settlement;

- Dispersed settlement.

Settlement with completely compact structure:

- Spontaneously formed settlement;

- Roadside village;

- Shantytown.

- Dispersed structure village settlement:

- Stari Vlah settlement;

- Ibar settlement;

- Shumadija settlement [Fig. 1].

1 Ђокић, В. Морфолошка истраживања у урбанизму // Часопис Архитектура и урбанизам. 2007. № 20/21. P. 61.

${ }^{2}$ Вреск, М. Основе урбане географије. 3., 1986. Р. 123.

3 Ђокић, В. Морфолошка истраживања у урбанизму // Часопис Архитектура и урбанизам. 2007. № 20/21. P. 61-62. 

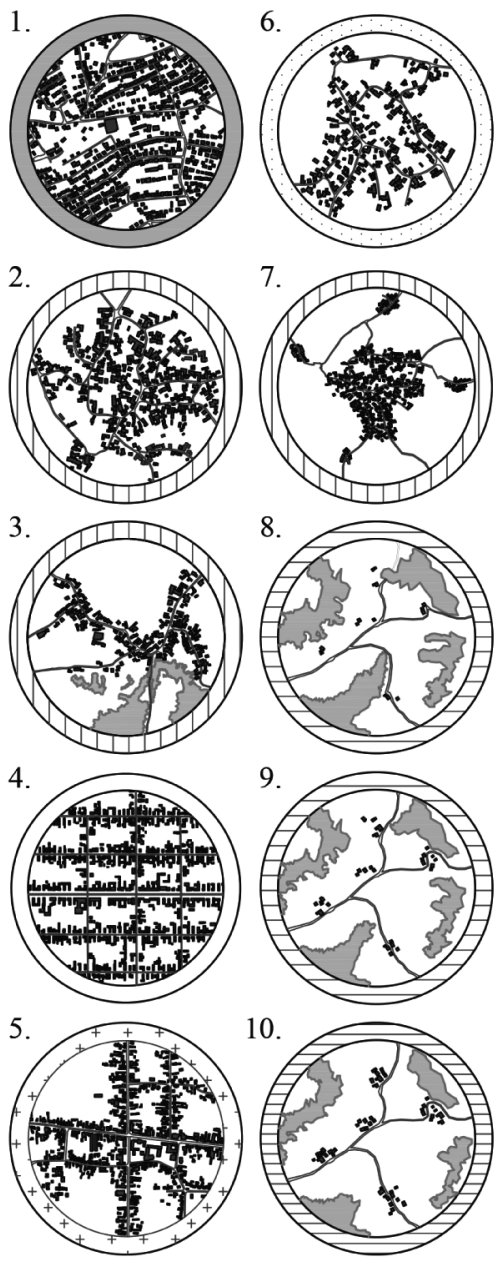

Villages with completely compact structure:

1. Slum (shantytown)

2. Spontaneously formed settlement

3. Roadside village

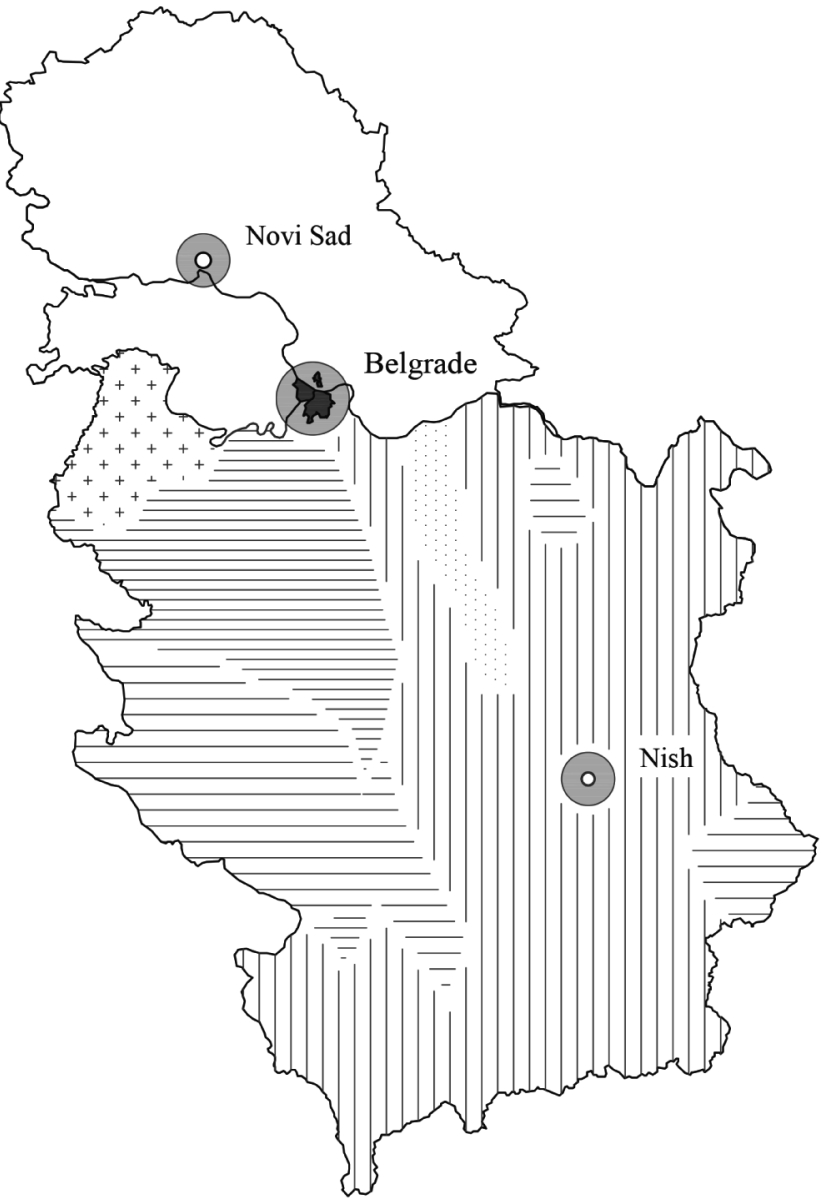

Semi-compact structure village settlemens:

4. Systematically developed (planned)

\section{settlements:}

Dispersed structure village

8. Stari Vlah settlement

9. Ibar village settlement

5. Subsequently planned settlement 10 . Shumadia settlement

6. Spontaneously formed settlement

7. Dispersed settlement

Fig. 1. Typology of Serbian village settlements by urban-morphological classification and their spatial distribution

(Рис. 1. Территориальное распределение морфологических типов сельских поселений в Республике Сербии)

Dispersed structure village settlements are subdivided into three groups, each representing one development level of the same architype, named after the geographical region in which it developed. These are: Stari Vlah, Ibar, and Shumadija subgroups. All dispersed villages are located south of the Sava and Danube rivers, and were formed spontaneously [6].

Stari Vlah subgroup of dispersed villages is spread over the mountains of Western and South-Western Serbia, with few additional enclaves in the other parts of the country. 
Main characteristic of these villages is the fact that they contain of individual households and small house groups scattered through almost entire village territory: village, as a spatial grouping, does not exists. Gross population density ranges from 1 to $5 \mathrm{p} / \mathrm{ha}^{1}$. Distances between houses are between 50 and $200 \mathrm{~m}$ by air.

Ibar subgroup is present in the same areas as Stari Vlah subgroup, from which they derived - simple by spatial densifying due to population increase; through several generations, one single estate evolved to a hamlet ${ }^{2}$, size up to 30 homes. Distance between hamlets span from 100 to $1000 \mathrm{~m}$ by air, while population density is between 10 and $15 \mathrm{p} / \mathrm{ha}$.

Shumadija subgroup is located exclusively in Central Serbia - Shumadija, after which it was named. Such settlements represent a last transition stage from villages with scattered structure to those with compact one. Their main characteristic is that settlement consists of several more or less distant group of homes, between which agricultural land is located. Shumadija subgroup village settlement is usually located at the $\operatorname{atar}^{3}$ center, so the distance between homes and agricultural land is considered favorable. The average population density is $15-25 \mathrm{p} / \mathrm{ha}$.

On the other hand, villages with semi-compact structure are characterized by average population density ranging from 20 to $25 \mathrm{p} / \mathrm{ha}$, and their construction area is easy to determine. By the manner of forming their urban matrix, they can be divided into two groups: those, in which aforementioned matrix is formed by external intervention (systematically developed (planned) settlements, and subsequently planned ones), and those in which this process took place spontaneously (spontaneously formed and dispersed village settlements).

Systematically developed settlements are located exclusively in the autonomous province of Vojvodina (part of the country north of the Sava and Danube rivers). They rose due to Austro - Hungarian planification of Vojvodina in $18^{\text {th }}$ century, when existing, spontaneously formed settlements were demolished, and their residents relocated to new ones, based on Baroque ides of an ideal city.

These villages are characterized by a completely regular, rectangular structure, consistently implemented from the parcel level (average size $40 \times 190 \mathrm{~m}$ ) to the level of the village itself - which often has a rectangular form too. As a part of the urban tissue, only centrally placed squares stand up; their form completely fits into the general scheme, and in most cases is formed by separating estates from neighboring blocks.

Subsequently planned villages are characteristic only for the Machva and Posavina regions. Speaking of such villages, we speak of cross-like shape villages, in which two main streets intersect each other at $90^{\circ}$ angle, forming a village center - a group concentration of central functions, which is, as a rule, characterized by the absence of the free space (village square). Households are touching each other with their edges perpendicular to the street. The average population density goes from 20 to $27 \mathrm{p} / \mathrm{ha}$. The

$1 \mathrm{P} /$ ha - People per hectare.

${ }^{2}$ Hamlet is a small human settlement. Usually, it is a subdivision of a village, his satellite entity. Is equivalent to Russian «хутор».

${ }^{3}$ Atar (Serb. - «aтар») - all village territories, consisting settlement(s), agricultural land, rivers, lakes, forests, etc. 
emergence of those settlements is linked to the efforts of the $19^{\text {th }}$ century Serbian authorities to model their villages after those from the neighboring Austro-Hungarian Empire.

In principle, spontaneously formed semi-compact and completely compact village settlements have the same morphological characteristics. The noticeable difference exists only in the household sizes, which consequently affects their population densities: gross population density goes from $20-25 \mathrm{p} /$ ha in semi-compact to $30-40 \mathrm{p} /$ ha for completely compact rural settlements [6-10].

The spatial distribution of those two types is identical. Kojic provides more information on their morphological structure: "The main structural characteristics of the older settlements in Kosovo and Metohija, and newer ones in Serbia proper (the latter rose as a result of migrations from the Old Serbia ${ }^{1}$ realm) are similar: a completely irregular street network, irregular house blocks and households. Road network was created on the default set of trails and primitive dirt roads, along which new households were formed. As a part of neighborhoods (inside which households are always touching each other), housing groups around dead end streets are also formed; it represents a regular occurrence in those kind of settlements"2.

Evolution of such settlements is relatively simple: if possible, they are further compacted by addition of new households, or - if this is impossible - they grow peripherally, maintaining an irregular structure.

In recent decades, three new subtypes of rural settlements came into appearance: dispersed village settlements, roadside village settlements, and shantytowns. The first two sub-groups have so far been placed in a group of "special settlements", while shantytowns have not yet been covered by any practical research.

Dispersed subtype of village settlements [Fig. 2] originates from spontaneously formed compact settlements, and is formed primarily due to agrarian overpopulation of the aforementioned. Therefore, in their spatial structure, we can clearly identify a basic, compact group of houses (hamlets), scattered through the village territory. As a rule, during the site selection for new housing units, settlers strive to make minimal impact to the arable land, so they densely group new households side by side. The average population density is in the range of $20-25 \mathrm{p} /$ ha, and the construction zone can be easily defined. For this reasons, we propose adopting dispersed village settlements as a sub-type of semicompact villages.

Genesis of roadside villages [Fig. 3] is linked exclusively to two concepts: de-agrarisation of the rural population ${ }^{3}$ and increased level of public safety. That is why households, previously set aside in relation to the main roads, now descent in their immediate vicinity. These settlements are characterized by a pronouncedly longitudinal spatial structure, formed solely around the dominant communication, and with an extremely dense construction, (average lot size is below $2000 \mathrm{~m}^{2}$ ). Due to aforementioned facts, the front

1 Territory of the medieval Serbian kingdom: Kosovo \& Metohija, Rashka (RS), Skopsko-Tetovska region (FYRM) [1].

2 Којић, Б. Сеоска архитектура и руризам: Теорија и елементи, Б., 1973. Р. 159 [5].

${ }^{3}$ According to official data, in 2015 , only $12 \%$ of the RS population was working in agriculture [2]. 
side of all households stretches all up to the road, lateral sides are touching each other, while the rear is usually output to agricultural land. The average population density is around $30-40 \mathrm{p} / \mathrm{ha}$.

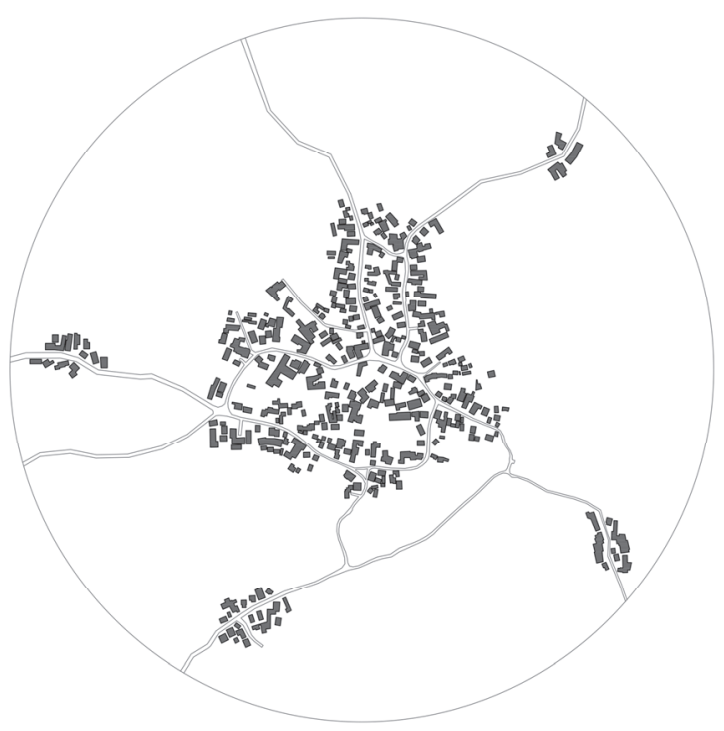

Fig. 2. Example of dispersed structure village settlement (Рис. 1. Пример поселения с разбитой морфологической структурой)

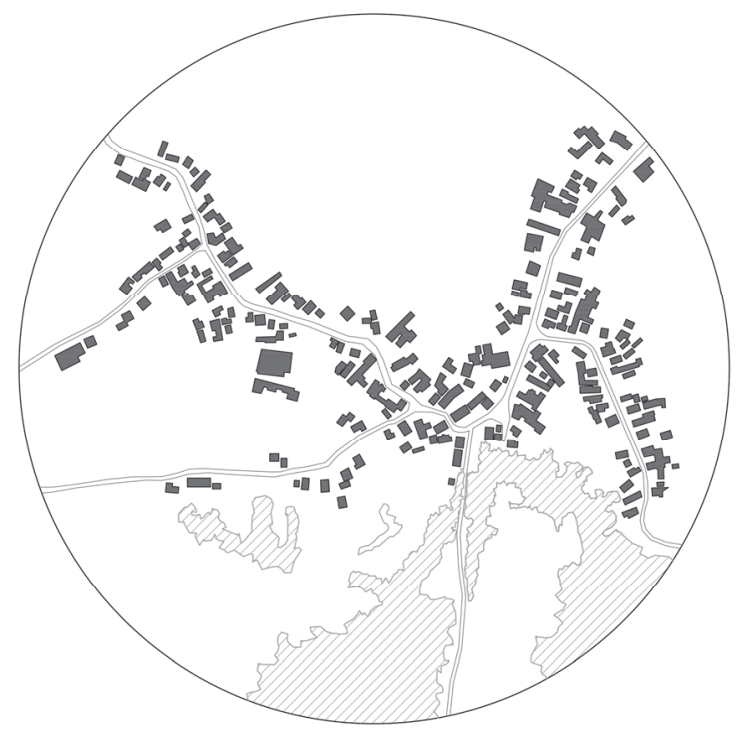

Fig. 3. Example of roadside village settlement

(Рис. 3. Пример придорожного сельского поселения)

In recent decades, due to catalyzation of unplanned city expansion, slums appeared as a special type of urban-rural settlement [Fig. 4]. First origins of such settlements are linked with the Yugoslav post-war reconstruction of the 1950's and rural - urban migrations from that period. Nevertheless, their ultimate expansion took place during 
the 1990s, when the socio-political changes in the Balkan Peninsula caused huge migrations [2].

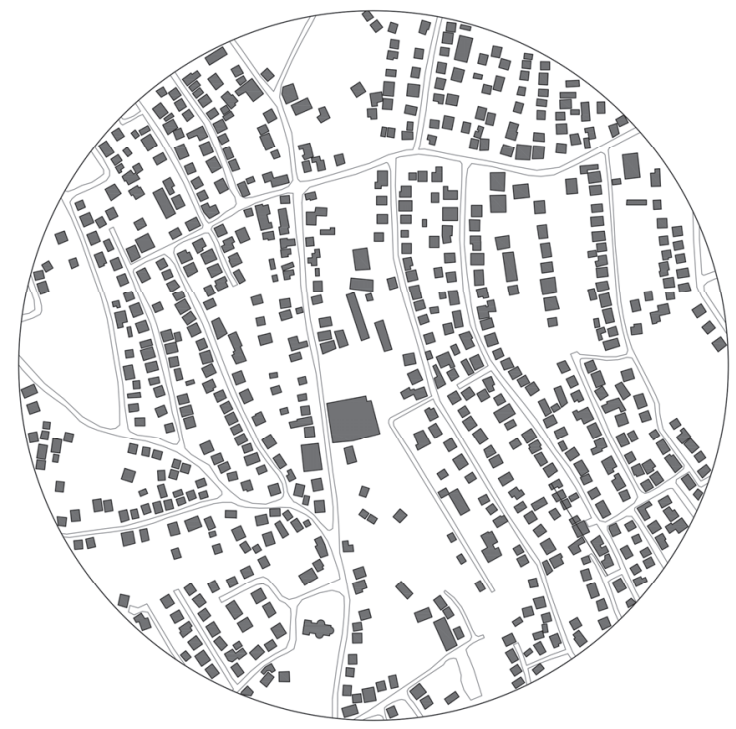

Fig. 4. Example of shantytown: Kaludjerica, Belgrade suburb, Serbia (Рис. 4. Пример самовольно построенного поселения: Калуджерица, пригород Белграда, Сербия)

Beside poor quality of subsequently built and often never finished dwellings, they are characterized by a minimal size lot (about $800-1000 \mathrm{~m}^{2}$ ), exclusively non-agricultural orientation of the population, and the lack of adequate municipal infrastructure. Both are determined by economic reasons. The difference compared to the basic type of spontaneous formed compact settlements is focus on expanding by adding floors (one for each son), to the existing residential building. Therefore, the population density of such settlements ranges up to $70 \mathrm{p} / \mathrm{ha}$.

Taking into account the above arguments, the adoption of the roadside village settlements and shantytowns as subtypes of village settlements with completely compact structure represents a logical conclusion - as they represent by-the-book examples of the groups they are placed into.

\section{REFERENCES}

[1] Terzich S. Stara Srbija (XIX-XX vek): Drama jedne tcivilizatcije. Novi Sad - Belgrade: Pravoslavna rech, Istorijski institut Beograd, 2012. (in Serb).

[2] Mitrovich M.M. Sela u Srbiji: Promene strukture i problemi odrzhivog razvoya. Belgrade: Republichki zavod za statistiku, 2015. (in Serb).

[3] Novikov V.A. Arhitekturnaja organizacija sel'skoj sredy. Moscow: Arkhitektura-S, 2005. (In Russ)

[4] Djokich V. Morfoloshka istrazhivanya u urbanizmu. Chasopis Arkhitektura i urbanizam. 2007. № 20/21. S. 61-72. (in Serb).

[5] Vresk M. Osnove urbane geografije. Zagreb: Shkolska kniga, 1986. (in Serb-Cro).

[6] Kojich B.Dj. Seoska arkhitektura i rurizam: Teoriya i elementi - drugo izdaniye, preradjeno. i dopunjeno. Belgrade: Izdavachko preduzeche Gradjevinska kniga, 1973. (in Serb). 
[7] Simonovich Dj.R., Ribar M.B. Uredjenye seoskih teritoriya i naselya: Urbanizatcija sela - drugo izdaniye, preradjeno i dopunjeno. Belgrade: Arhitektonski fakultet Univerziteta u Beogradu, 1993. (in Serb).

[8] Ribar M. Savremeni rurizam. Belgrade: Tcentar za multidistciplinarne studije Univerziteta u Beogradu, 1988. (in Serb).

[9] Videnovich A.Ch. Revitalizatciya tcentara u selima brdsko-planinskikh podruchja Istochne Srbije [dissertation]. Belgrade, 2016. Available from: http://www.arh.bg.ac.rs/wp-content/uploads/ Doktorati/2016/2016_27_Aleksandar_Videnovic_disertacija.pdf?pismo=lat (in Serb).

[10] Findrik R. Dinarska brvnara. Sirogojno: Muzej “Staro selo”, 1998. (in Serb).

(C) Dopudja D., 2017

Article history:

Received: May 2017

Accepted: September 2017

For citation:

Dopudja D. (2017) Appendix to the classification of rural settlements in the Republic of Serbia, according to their urban-morphological characteristics. RUDN Journal of Engineering Researches, 18(2), 382-390. DOI 10.22363/2312-8143-2017-18-3-382-390

\title{
Bio Note:
}

Dopudja D., Postgraduate of Department of Architecture and Construction, Academy of Engineering of Peoples' Friendship University of Russia. Contact information: e-mail: dusan. dopudja@yandex.ru

\section{ПРИЛОЖЕНИЕ К КЛАССИФИКАЦИИ СЕЛЬСКИХ ПОСЕЛЕНИЙ В РЕСПУБЛИКЕ СЕРБИИ ПО МОРФОЛОГИЧЕСКИМ ХАРАКТЕРИСТИКАМ}

\author{
Д. Допуджа \\ Российский университет дружбы народов \\ ул. Миклухо-Маклая, 6, Москва, Россия, 117198
}

В статье представлен метод пространственного анализа застройки с морфологического аспекта на примере аналитического обзора сербских сельских поселений. Обзор содержит обновления, отражающие произошедшие в последние несколько десятилетий изменения в сельской среде Сербии.

Ключевые слова: деревня, поселение, сельский, градостроительная морфология, генезис, пространственное развитие, пересмотр классификации

\section{СПИСОК ЛИТЕРАТУРЫ}

[1] Терзић С. Стара Србија (XIX-XX век): Драма једне цивилизације. НС-Б.: Православна реч, Историјски институт Београд, 2012.

[2] Митровић М.М. Села у Србији: Промене структуре и проблеми одрживог развоја. Б.: Републички завод за статистику, 2015. 
[3] Новиков B.A. Архитектурная организация сельской среды. М.: Архитектура-С, 2006.

[4] Ђокић $B$. Морфолошка истраживања у урбанизму // Часопис Архитектура и урбанизам. 2007. № 20/21. C. 61-72.

[5] Вреск М. Основе урбане географије. З.: Школска књига, 1986.

[6] Којић Б. Сеоска архитектура и руризам: Теорија и елементи - друго издање, прерађено и допуњено. Б.: Издавачко предузеће Грађевинска књига, 1973.

[7] Симоновић Ђ.Р., Рибар М.Б. Уређење сеоских територија и насеља: Урбанизација села друго издање, прерађено и допуњено. Б.: Архитектонски факултет Универзитета у Београду, 1993.

[8] Рибар М. Савремени руризам. Б.: Центар за мултидисциплинарне студије Универзитета у Београду, 1988.

[9] Виденовић А.Ч. Ревитализација центара у селима брдско-планинских подручја Источне Србије: дисс. ... канд. арх., Београд, 2016. URL: http://www.arh.bg.ac.rs/wp-content/uploads/ Doktorati/2016/2016_27_Aleksandar_Videnovic_disertacija.pdf?pismo=lat (дата обращения: 12.08.2017).

[10] Финдрик Р. Динарска брвнара. С.: Музеј «Старо село», 1998.

\section{История статьи:}

Дата поступления в редакцию: май 2017

Дата принятия к печати: сентябрь 2017

\section{Для цитирования:}

Допуджа Д. Приложения к классификации сельских поселений в Республике Сербии по морфологическим характеристикам // Вестник Российского университета дружбы народов. Серия: «Инженерные исследования». 2017. Т. 18. № 3. С. 382-390. DOI 10.22363/2312-81432017-18-3-382-390

\section{Сведения об авторе:}

Допуджа Душан, аспирант департамента архитектуры и строительства инженерной академии Российского университета дружбы народов. Контактная информация: e-mail: dusan. dopudja@yandex.ru 